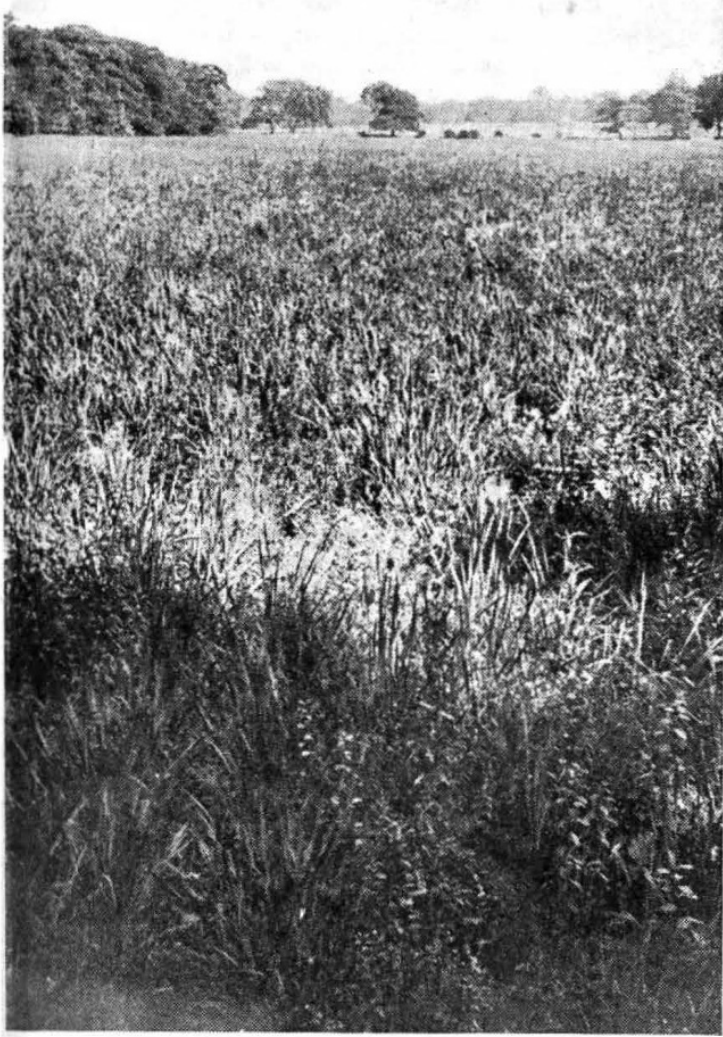

Crown copyright reserved

Fig. 2. Vegetation Covering the BED OF BINLEY IAKE TEN MONTHS AFTER DRAINING

re-stocked. It was considered that until the Lake was reasonably clear of rotting vegetation, the oxygen content of the water would be too low to justify re-stocking with fish. It was also doubtful whether 6-8 $\mathrm{ft}$. of water would be sufficient to kill the vigorous growth which had arisen during the two years the Lake had been empty.

The owners were therefore advised that the vegetation should be cut close down in the spring, the autumn and the following spring before the Lake was re-flooded. Compensation was based upon this suggestion, and allowance was made for a reasonable period before the Lake and its fish could be expected to have recovered full fishing value. The owners decided, however, not to incur the expense of cutting, and they re-flooded the Lake in October 1944, almost exactly two years after it had been drained.

A visit to the Lake in August 1947 showed that during two seasons a few men had been employed in pulling out the bullrushes and similar growth which showed above the surface. In March 1946 there were large areas of open water with belts of reedmace at the shores. Some eight thousand roach, bream, pike, rudd and tench were then put in; a further seven thousand, with some golden carp, were added in September 1946. All seemed well until in July 1947 a strong growth of hornwort (Ceratophyllum demersum) developed in almost every part of the Lake. The growth extended to the surface in many places, where it entrained a quantity of ordinary pond weed and made fishing almost impossible. The fish, however, appeared to thrive. No dead fish have been seen, and those caught show good growth and are in good condition.

The problem now is to find what action can be taken without injury to the fish to avoid the growth of weed in subsequent years.

Dr. W. B. Turrill and Mr. V. S. Summerhayes, of Kew, visited the Lake in December 1943, and a brief summary of their findings is appended.

\section{VEGETATION AFTER DRAINING}

\section{By V. S. SUMMERHAYES and DR. W. B. TURRILL}

A visit to Binley Lake was made on December 2, 1943, under the guidance of Mr. F. P. Knight, of the Directorate of Camouflage. The Lake had been drained and its bed was occupied by a dense growth of vegetation fairly uniformly spread over the whole area. The dominant plant was the reedmace (Typha latifolia), except in a few small patches where other species (mainly Phragmites communis and Carex sp.) had obviously established themselves, previous to the draining, in shallow water against the shore. The reedmace plants were up to $6-8 \mathrm{ft}$. in height, and a very large number of them were in full fruit. Though they were distributed over the whole lake bed, the mature plants of reedmace were somewhat denser in some parts than in others. In places willows (Salix caprce and $S$. viminalis) had become established and were $8 \mathrm{ft}$. tall. Locally these willows were abundant. The reed grasses Phragmites communis and Glyceria maxima occurred in a few places, and many marsh and some dry-land species were listed as present in one to several individuals. It was fully established, from the morphology of the Typha and other plents, that this remarkable growth of vegetation had occurred within one year. The botanical evidence was in complete agreement with the dated records that the fruiting Typha plants had developed from seedlings in less than twelve months, a surprising rapidity of growth from establishment on bare mud.

The vegetation was only partially closed. In many places, leaves of separate plants touched or overlapped, but there was mostly bare mud between individual plants. On this mud were innumerable seedlings of Typha, low-growing marsh plants, some in flower or fruit, and mosses. The presence of mosses was not unexpected; but the species represented were mostly well-known dry land ones. Far and away the most abundant was a form of Funaria hygrometrica, which sometimes appeared in continuous patches a foot or more square, but more often in smaller clumps. Other species present in fair quantity, but scattered throughout much of the area of the lake bed, were : Barbula unguiculata, B. tophacea, Bryum argenteum, and Bryum sp. (barren). Small quantities of Webera carnea and Dicranella heteromalla were also noticed, and one patch of the liverwort Marchantia polymorpha was found near the inlet end of the Lake.

The reedmace which, at the time of the visit, had so largely occupied the mud, must have spread as seeds from near the top (inflow) end of the Lake, where there was an old-established community of this species forming what had evidently been a Typha swamp. No other Typha was found growing in or near the Lake, except the young plants and seedlings all less than a year old. 